\title{
Pathogenicity of entomopathogenic fungus Metarhizium spp. against predators Menochilus sexmaculatus Fabricius (Coleoptera: Coccinellidae)
}

\author{
TRIZELIA ${ }^{\vee}$, MUNZIR BUSNIAH, AGUNG PERMADI \\ Department of Plant Protection, Faculty of Agriculture, Universitas Andalas. Limau Manis Campus, Padang 25163, West Sumatra, Indonesia. Tel.: +62- \\ 751-72701, Fax.: +62-751-72702, `email: trizelia@yahoo.com
}

Manuscript received: 30 January 2017. Revision accepted: 17 March 2017.

\begin{abstract}
Trizelia, Busniah M, Agung Permadi A. 2017. Pathogenicity of entomopathogenic fungus Metarhizium spp. against predators Menochilus sexmaculatus Fabricius (Coleoptera: Coccinellidae). Asian J Agric 1: 1-5. Metarhizium spp is an entomopathogenic fungus that has wide host range. Metarhizium spp can not only infect insect pests, but can also infect beneficial insects such as predators. The pathogenicity of four isolates of Metarhizium spp. was investigated against Menochilus sexmaculatus predators. Isolates of Metarhizium spp were isolated from rhizosphere of cacao, cabbage, chili and rubber crops. The experiment was conducted by treating the fourth instar larvae with an appropriate conidial suspension of $10^{8}$ conidia $\mathrm{mL}^{-1}$. The results showed that all isolates of Metarhizium spp were pathogenic toward beetle predator M. sexmaculatus. Mortality of larvae within 7 days after application of conidial suspension varied between 27.50 to $67.50 \%$ and there were statistically significant differences among the tested isolates. Metarhizium spp. had also a significant effect in reducing pupation and adult emergence of $M$. sexmaculatus to below 30\% and 3\%, respectively. These studies indicate that entomopathogenic fungus Metarhizium spp was pathogenic to beetle predators, M. sexmaculatus
\end{abstract}

Keywords: Beetle predators, entomopathogenic fungus, Menochilus sexmaculatus, Metarhizium

\section{INTRODUCTION}

Entomopathogenic fungi have been used in control of several insect pests as alternative to chemical insecticides (Hajek and Leger, 1994). Among these entomopathogenic fungi, Metarhizium spp have great potential as biological control agents against insects pest and as a component within integrated pest management systems. Utilization of Metarhizium spp. for pest control has been widely reported. Trizelia et al (2011) reported that fungus Metarhizium spp can kill Spodoptera litura eggs. Mortality of S. litura eggs depends on the fungal isolates, ranging between $19.79 \%$ $75.70 \%$. First instar larvae also die 3 days after eclosion. The maximum mortality of first instar larvae was $58.65 \%$. Nunilahwati (2012) reported that Metarhizium spp can also infect Plutella xylostella larvae and the mortality of larvae up to $82 \%$ with LT $_{50}$ value 2.26 days. Saranya et al (2010) reported that mortality of aphids, Aphis craccivora was $80.76 \%$ observed in $168 \mathrm{~h}$, at the highest concentration $\left(10^{8}\right.$ spores $\mathrm{mL}^{-1}$ ) of Metarhizium anisopliae.

One of the most important aspects that should be considered in the use of Metarhizium spp as biological control agents, is the wide compatibility with other biological control agents such as insect predator Menochilus sexmaculatus. This is due to the fact that this fungus can infect many kinds of insects, both predators and pests. Although some entomopathogenic fungi are known to have narrow host ranges, especially some of those belonging to Deuteromycotina, they have a rather wide range of hosts from many insect orders, including natural enemies (Inglis et al. 2001). Compatibility between entomopathogenic fungi and predators is required to minimize risk to the environment.

Menochilus sexmaculatus beetle predators (Coleoptera: Coccinellidae) are one of the biological control agents. These predators feed on Lipaphis erysimi nymphs (Ali and Rizvi, 2009). Adults of M. sexmaculatus were able to prey on Aphis gossypii on an average rate of 44.50 individuals per hour (Nelly et al.2012). Solangi et al. (2007) reported that the mean number of prey consumed by $M$. sexmaculatus during entire adult life was 80.08, 69.95 and 68.96 of $R$. maidis, A. gosypii and T. trifolii respectively. This beetle has great potential to be a biological control of these three aphid species. Radiyanto et al (2011) reported that the maximum number of prey consumed by adult $M$. sexmaculatus females, was 300 individuals at various stages of Rhopalosiphum maidis Fitch (Homoptera: Aphididae) per $24 \mathrm{~h}$. Ali et al (2012) found that the predatory potential of male M. sexmaculatus on Rhopalosiphum padi was 2294 to 2422 and female was 2912 to 3085 aphids.

An understanding of the interaction between entomopathogenic fungi Metarhizium spp and predator $M$. sexmaculatus in agricultural ecosystems is needed to predict the environmental impact of Metarhizium spp application to the development of predator populations. In addition to direct contact with entomopathogenic fungi, predators can also be threatened by consuming fungus infected prey. Er et al (2008) reported that Metarhizium anisopliae (Metschnikoff) Sorokin. was generally found to be pathogenic to Coccinella septempunctata and the mortality of adults was $47.61 \%$. While $\mathrm{Wu}$ et al (2014) reported that $B$. bassiana strain SZ-26 showed high toxicity 
against Frankliniella occidentalis (Pergande) (Thysanoptera: Thripidae) but not a detrimental effect to predatory mite Neoseiulus (Amblyseius) barkeri (Hughes) (Acarina: Phytoseiidae).

The purpose of this research was to study the pathogenicity of several isolates of Metarhizium spp against a predatory beetle Menochilus sexmaculatus.

\section{MATERIALS AND METHODS}

\section{Fungal isolates}

The isolates of Metarhizium spp. used was from the collection of the Laboratory of Biological Control, Department of Plant Pests and Diseases, Faculty of Agriculture, University of Andalas, Padang, Indonesia. Isolates were isolated from rhizosphere of cacao, rubber, pepper and coffee crops from various locations (Table 1). All isolates were grown on SDAY (Sabouraud dextrose agar + yeast extract) medium.

\section{Aphids and M. sexmaculatus culture}

Aphids (Aphis maydis and A. craccivora) and $M$. sexmaculatus predators were collected from the corn and long bean fields in the city of Padang and brought to the laboratory. Predators were reared in the laboratory on this aphid species in wide-mouth plastic jars. Fresh stock of leaves respective for aphids hosts were provided daily as oviposition substrate for female beetles. The eggs laid by female beetles on aphids-host leaves were transferred to plastic box for further rearing. The newly hatched larvae were reared to the fourth instar to be used as test insects.

\section{Preparation of conidial suspension}

Isolates of Metarhizium spp. were grown using autoclaved SDAY media. The fungal cultures were incubated at $25^{\circ} \mathrm{C}$ for 15 days. Cultures with fully developed conidiospores were washed by $5 \mathrm{~mL}$ sterilized distilled water mixed with $0.05 \%$ Tween 80 to obtain the stock of conidial suspension. The conidial suspensions were passed through two layers of sterile muslin to remove any agar pieces and hyphae from the conidial suspensions. Conidia were counted in a compound microscope using a Neubauer hemocytometer.

\section{Pathogenicity test}

The conidial density was used $10^{8}$ conidia $\mathrm{mL}^{-1}$ for all isolates. Two $\mathrm{mL}$ of the suspension was sprayed against the fourth instar larvae of M. sexmaculatus tested. For the control, larvae were sprayed with the same volume of distilled water mixed with $0.05 \%$ Tween 80 . Then the fourth instar larvae of $M$. sexmaculatus were kept in the box provided. Each box contained only one of the fourth instar larvae of $M$. sexmaculatus. Each experimental unit consisted of 10 fourth instar larvae of $M$. sexmaculatus. The experiment was repeated four times. The mortality of larvae was recorded at $24 \mathrm{~h}$ intervals until adult emergence. Parameters observed were larval mortality, pupation, adult emergence and the ability of $M$. sexmaculatus to prey on aphids.

\section{Data analysis}

This experiment was arranged in the Completely Randomized Design (CRD) and data were analyzed by means of the analysis of variance (ANOVA) and Duncans Multiple Range Test (DNMRT) $(\mathrm{P}=0.05 \%)$.

\section{RESULTS AND DISCUSSION}

The results of pathogenicity test showed that all of the Metarhizium spp. isolates were pathogenic on the larvae of Menochilus sexmaculatus. Mortality of M. sexmaculatus larvae after application of Metarhizium spp., depended on the isolates. Metarhizium spp isolates tested induced cumulative mortalities between 27.50 to $67.50 \%$ in fourth instar larvae of M. sexmaculatus. ANOVA test revealed statistically significant differences amongst the treatments $(\mathrm{F}=16.85 ; \mathrm{P}<0.05)$. All the Metarhizium spp isolates applied gave significant higher mortality than the control unit (Table 2). Three isolates (MetAKi, MetLKt and MetPKo) caused higher mortality (62.5-67.5\%) on the fourth instar larvae, while MetKbCi isolates showed the lowest degree of pathogenicity $(27.50 \%)$.

The fourth instar larvae of $M$. sexmaculatus infected by entomopathogenic fungi Metarhizium spp. was covered by fungus mycelia or conidia having green in color around the body surface $M$. sexmaculatus larvae (Figure 1).

The mortality of $M$. sexmaculatus larvae after Metarhizium spp application was due to the fact that Metarhizium spp was able to kill not only the pest insect but also predators. This is caused by the body structure of both being almost the same. Thungrabeab and Tongma (2007) reported that Metarhizium anisopliae could kill Dicyphus tamanii (Hymenoptera; Miridae) up to $10 \%$ and Carnea chrysoperla (Neuroptera; Chrysopidae) up to $4 \%$ at density of conidia $10^{8}$ conidia $\mathrm{mL}^{-1}$. The same result was also found by Ibrahim et al (2011) that isolates of Metarhizium spp. caused mortality for Cryptolaemus montrouzieri (Coleoptera; Coccinellidae) larvae about 7.7 $\%$. Er et al (2008) also reported that Metarhizium anisopliae caused mortality of Coccinella septempunctata (Coleoptera; Coccinellidae) adults up to $47.61 \%$. Sahayaraj et al (2008) reported that the survival rate and the particle carrying capacity of reduviid predator, Acanthaspis pedestris were reduced after application of Metarhizium anisopliae compared to the control. While Huang et al (2012) reported that there are no adverse effects of entomopathogenic fungus Beauveria bassiana application on the survival and reproduction of predator Prynocaria congener (Coleoptera; Coccinellidae).

Difference in pathogenicity among isolates is common for entomopathogenic fungi. Differences in pathogenicity among isolates were attributed to the differences in the ability to produce enzymes and mycotoxins during the infection process in insects such as the time of contact with the cuticle and hemocoel (Tanada and Kaya, 1993; Balachander et al. 2012). A toxin called destruxin which is produced by Metarhizium spp during infection was thought to be the cause of $M$. sexmaculatus death. 


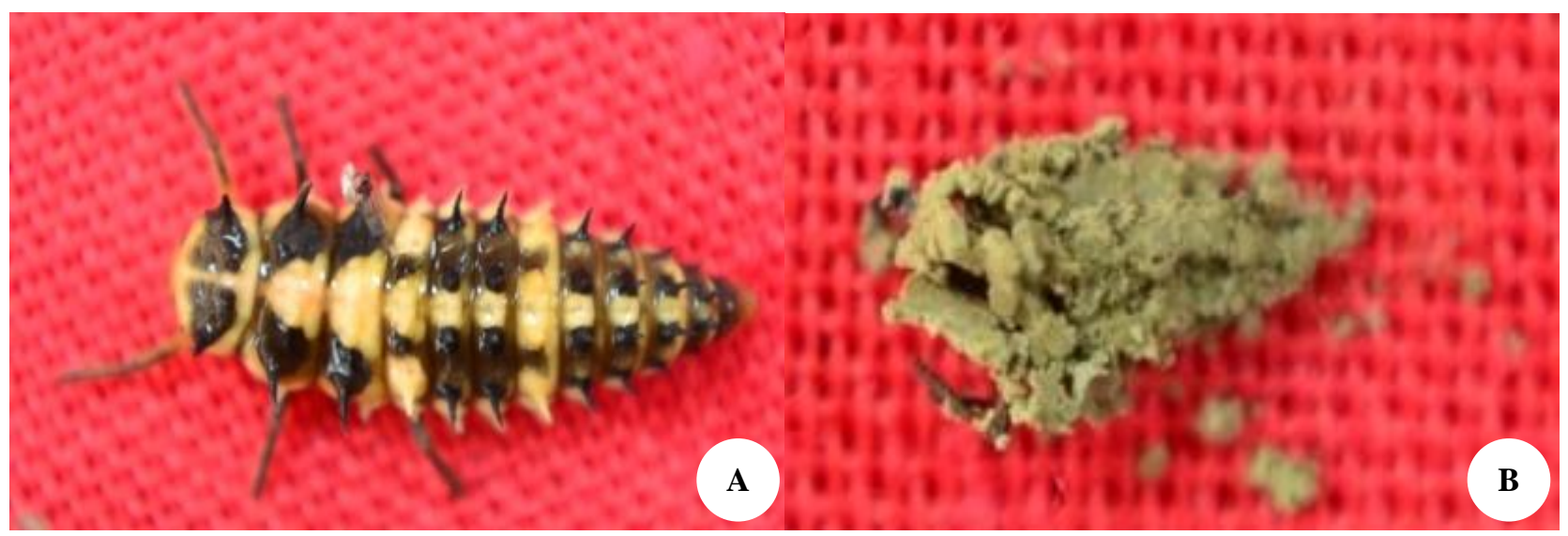

Figure 1. The fourth instar larvae of M. sexmaculatus in form of normal (A) and infected by entomopathogenic fungi Metarhizium spp. (B)

Table 1. The source of Metarhizium spp. isolates

\begin{tabular}{lll}
\hline Isolate & Host & Origin \\
\hline MetPKo & Cacao & Pariaman \\
MetLKt & Rubber & Lintau (Tanah Datar) \\
MetKbCi & Chili & Koto Baru (Tanah Datar) \\
MetAKi & Coffee & Matur (Agam) \\
\hline
\end{tabular}

Table 2. Mortality of the fourth instar larvae of $M$. sexmaculatus after application of four isolates of Metarhizium spp with density conidia $10^{8}$ conidia/mL.

\begin{tabular}{ll}
\hline Isolates & Mortality \pm SD $(\%)$ \\
\hline MetAKi & $67.50 \pm 9.57 \mathrm{a}$ \\
MetLKt & $65.00 \pm 17.32 \mathrm{a}$ \\
MetPKo & $62.50 \pm 9.57 \mathrm{a}$ \\
MetKbCi & $27.50 \pm 18.93 \mathrm{~b}$ \\
Control & $7.50 \pm 5.00 \mathrm{c}$ \\
\hline
\end{tabular}

Note: Different letters indicate a statistically significant difference according to DNMRT test, $\mathrm{P}<0.05$

Besides killing larvae, fungi infections also affected the development of pupae. The amount of pupae formed (pupation) is inversely related to the mortality of larvae. Based on the analysis of variance, the percentage of pupae formed was significantly different among isolates $(\mathrm{F}=17.20 ; \mathrm{P}<0.05)$, (Table 3$)$. The highest percentage of pupa formed $(70 \%)$ were found under application of isolate MetKbCi, while the lowest was under MetPKo, MetLKt and MetAKi.

As for larvae, pupae $M$. sexmaculatus infected by entomopathogenic fungi Metarhizium spp. were also covered by the fungal mycelia or conidia having green color at the body surface (Figure 2).

Percentage of adult emergence from larvae infected by Metarhizium spp. also reduced significantly. Application of Metarhizium spp. could only generate adults about $2.5 \%$ $27.5 \%$, while the control could reach $90 \%$ (Table 4).
Metarhizium spp. had also a significant effect in reducing pupation of $M$. sexmaculatus and adult emergence to below $30 \%$ and $3 \%$, respectively. The low percentage of pupation and adult emergence was due to the fact that a high number of larvae and pupae were killed before becoming adult. This proves that the influence of Metarhizium spp. was not only active and destructive in certain stadia treated, but also had an impact on subsequent stadium. Malarvannan et al (2010) reported that entomopathogenic fungi, Beauveria bassiana can reduce pupation and adult emergence of Spodoptera litura, due to phagodepression and difficulty in molting.

The ability to prey on aphids of unapplied $M$. sexmaculatus larvae by Metarhizium spp. was also significantly different from those applied $M$. sexmaculatus ( $\mathrm{P}<0.0001)$ (Table 5). In control, the predation ability of $M$. sexmaculatus on aphids reached 10.63 individuals per hour, while the predation ability of predators sprayed with entomopathogenic fungi, decreased significantly (from 6.93 to 1.08 individuals per hour).

The ability of the fourth instar larvae of $M$. sexmaculatus to prey on aphids was generally decreased following fungal infection. The reduction in preying insects was assumed due to production of toxic substances by fungi or mechanical disruption of the insect structural integrity by hyphal growth. Destruction affected target cell organelles (mitochondria, endoplasmic reticulum and nuclear membrane) and caused paralysis of cells. It also affected the mesenteron, Malpighian tubes, and tissue larval hemocyte dysfunction (Tanada and Kaya, 1993).

Based on the research conducted, it can be concluded that all isolates of Metarhizium spp tested were pathogenic to predators $M$. sexmaculatus. The lowest pathogenicity $(27.5 \%)$ isolates were found at MetKbCi, while the isolates MetPKo, MetLKt and MetAKi had high pathogenicity $(62.50 \%, 65 \%$, and $67.50 \%$ respectively). Further research is required to determine how direct effects observed in laboratory play out in a field environment. 


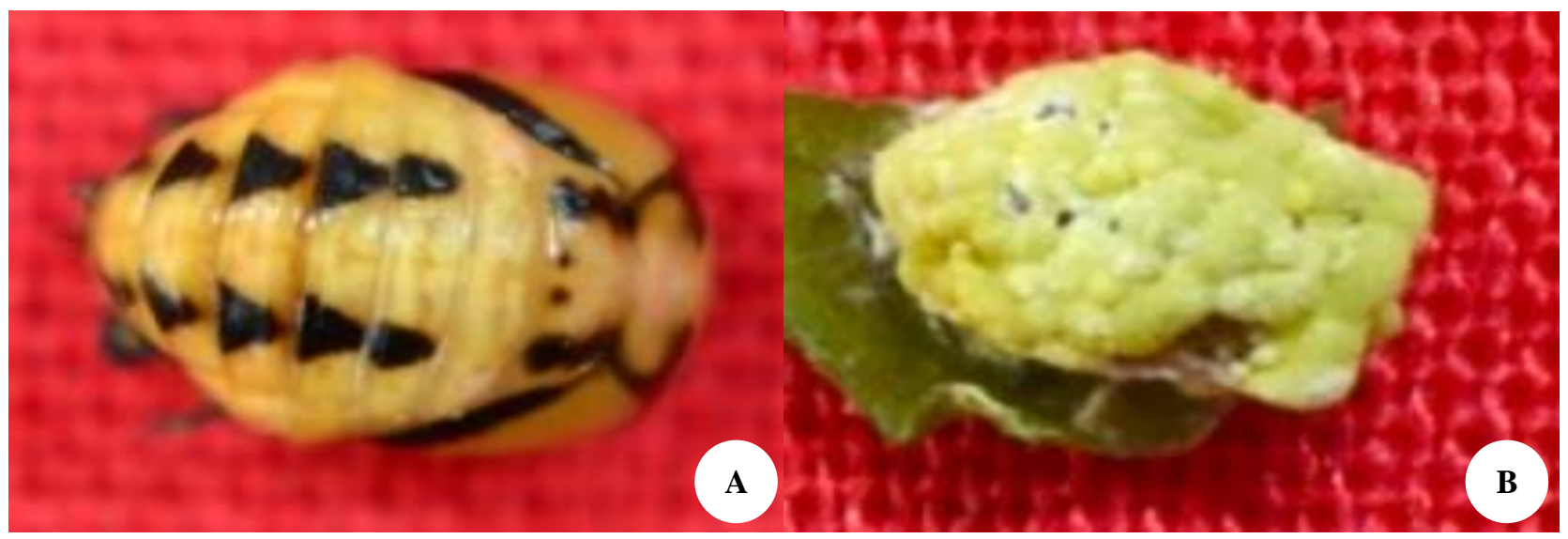

Figure 2. Pupae of M. sexmaculatus in form of normal (A) and infected by entomopathogenic fungi Metarhizium spp. (B)

Table 3. Formation of M. sexmaculatus pupae

\begin{tabular}{ll}
\hline Isolates & Pupae formed $\pm \mathbf{S D}(\boldsymbol{\%})$ \\
\hline Control & $92.50 \pm 5.00 \mathrm{a}$ \\
MetKbCi & $70.00 \pm 20.00 \mathrm{~b}$ \\
MetPKo & $32.50 \pm 8.16 \mathrm{c}$ \\
MetLKt & $30.00 \pm 17.08 \mathrm{c}$ \\
MetAKi & $27.50 \pm 9.58 \mathrm{c}$ \\
\hline
\end{tabular}

Note: Different letters indicate a statistically significant difference according to DNMRT test, $\mathrm{P}<0.05$

Table 4. Percentage of adult emergence of M. sexmaculatus

\begin{tabular}{ll}
\hline Isolates & Adult emergence \pm SD $(\boldsymbol{\%})$ \\
\hline Control & $90.00 \pm 0.00 \mathrm{a}$ \\
MetAKi & $27.50 \pm 5.00 \mathrm{~b}$ \\
MetLKt & $15.00 \pm 12.91 \mathrm{~b} \mathrm{c}$ \\
MetKbCi & $15.00 \pm 23.81 \mathrm{~b} \mathrm{c}$ \\
MetPKo & $2.50 \pm 5.00 \mathrm{c}$ \\
\hline
\end{tabular}

Note: Different letters indicate a statistically significant difference according to DNMRT test, $\mathrm{P}<0.05$

Table 5. The predation ability on aphids of $M$. sexmaculatus larvae for $1 \mathrm{~h}$ after $24 \mathrm{~h}$ application of Metarhizium spp.

\begin{tabular}{lc}
\hline Isolates & Ability of predation (ind./hour) $\mathbf{\pm S D}$ \\
\hline Control & $10.63 \pm 1.56 \mathrm{a}$ \\
MetPKo & $6.93 \pm 0.41 \mathrm{~b}$ \\
MetLKt & $4.35 \pm 0.79 \mathrm{c}$ \\
MetAKi & $1.48 \pm 0.22 \mathrm{~d}$ \\
MetKbCi & $1.08 \pm 0.21 \mathrm{~d}$ \\
\hline
\end{tabular}

Note: Different letters indicate a statistically significant difference according to DNMRT test, $\mathrm{P}<0.05$

\section{REFERENCES}

Ali A, Rizvi PQ. 2009. Life Table studies Menochilus sexmaculatus Fabr (Coleoptera:Coccinellidae) at varying temperatures on Lipaphis erysimi Kalt. World Appl Sci J 7 (7): 897-901.
Ali A, ul-Haq E, Rehman A, Khan J, Gillani WA, Rauf M. 2012. Biological parameters and predatory potential of Menochilus sexmaculatus Fab. (Coleoptera: Coccinellidae) at varying temperature on Rhopalosiphum padi L. Pakistan J Agric Res 25 (4): 318-322.

Balachander M, Remadevi OK, Sasidharan TO, Bai NS. 2012. Virulence and mycotoxic effects of Metarhizium anisopliae on Mahogany shoot borer, Hypsipyla robusta (Lepidoptera: Pyralidae). J Forestry Res 23 (4): 651-659.

Er MK, Tunaz H, Isikber AA, Satar S, Mart C, Uygun N. 2008. Pathogenicity of entomopathogenic Fungi to Coccinella septempunctata (Col.: Coccinellidae) and a survey of fungal diseases of Coccinellids. KSU J Sci Engin 11 (1): 118-122.

Hajek AE, St. Leger RJ. 1994. Interactions between fungal pathogens and insect hosts. Annu Rev Entomol 39:293-322

Huang Z, Ali S, Ren S, Wu J, Zhang Y. 2012. Influence the entomopathogenic fungus Beauveria bassiana on Prynocaria congener Bilberg (Coleoptera; Coccinellidae) under laboratory conditions. Pakistan J Zool 44 (1): 209-216.

Ibrahim L, Hamieh A, Ghanem H, Ibrahim SK. 2011. Pathogenicity of Entomopathogenic Fungi from Lebanese Soils Against Aphids, Whitefly and Non-Target Beneficial Insects. Intl J Agric Sci 3: 156164.

Inglis GD, Goettel MS, Butt TM, Strasser H. 2001. Use of Hyphomycetous fungi for managing insect pests. In: Butt TM, Jackson C, Magan N (eds). Fungi As Biocontrol Agents: Progress, Problems and Potential. CABI Publishing, Bristol, UK.

Malarvannan S, Murali PD, Shanthakumar SP, Prabavathy VR, Nair S. 2010. Laboratory evaluation of the entomopathogenic fungi, Beauveria bassiana against the Tobacco caterpillar, Spodoptera litura Fabricius (Noctuidae: Lepidoptera). J Biopesticides 3: 126 - 131.

Nelly N, Trizelia, Syuhadah Q. 2012. Tanggap fungsional Menochilus sexmaculatus Fabricius (Coleoptera: Coccinellidae) terhadap Aphis gossypii (Glover) (Homoptera: Aphididae) pada umur tanaman cabai berbeda. J Entomol Ind 9 (1): 23-31.

Nunilahwati H, Herlinda S, Irsan C, Pujiastuti Y. 2012. Eksplorasi, isolasi dan seleksi jamur entomopatogen Plutella xylostella (Lepidoptera: Yponomeutidae) pada pertanaman caisin (Brassica chinensis) di Sumatera Selatan. J Hama dan Peny Tumb Tropika, 12 (1): 1-11

Radiyanto I, Rahayuningtias S, Widhianingtyas E. 2011. Kemampuan Pemangsaan Menochilus sexmaculatus F. (Coleoptera: Coccinellidae) terhadap Rhopalosiphum maidis Fitch (Homoptera: Aphididae). J Entomol Ind 8 (1): 1-7.

Sahayaraj K, Lalitha A, Balasubramanian R. 2008. Biosafety of Metarhizium anisopliae (Metschinikoff) Sorokin on a reduviid predator Acanthaspis pedestris (Hemiptera: Reduviidae). Hexapoda 15 (1): 46- 48.

Solangi BK, Hullio MH, Baloch N. 2007. Biological parameters and prey consumption by zigzag beetle Menochilus sexamaculatus Fab. against Rhopalosiphum maidis Fitch, Aphis gossypii Glov. and Therioaphis trifolii Monell. Sarhad J Agric 23 (4): 1097-1101.

Tanada Y, Kaya H K . 1993. Insect Pathology. Academic Press. Inc., California. 
Thungrabeab M, Tongma S. 2007. Effect of entomopathogenic fungi, Beauveria bassiana (Balsam) and Metarhizium anisopliae (Metsch) on non target insects. KMITL Sci Tech J 7: 8-12

Trizelia, Syahrawati M, Mardiah A. 2011. Patogenisitas Beberapa Isolat Cendawan Entomopatogen Metarhizium spp. terhadap Telur Spodoptera litura Fabricius (Lepidoptera: Noctuidae). J. Entomol Ind 8 (1): 45-54. [Indonesian]
Wu S, Gao Y, Zhang Y, Wang E, Xu X, Lei Z. 2014. An entomopathogenic strain of Beauveria bassiana against Frankliniella occidentalis with no detrimental effect on the predatory mite Neoseiulus barkeri ?: Evidence from laboratory bioassay and Scanning Electron Microscopic observation. PLoS ONE 9 (1): e84732. DOI: 10.1371/journal.pone.0084732 